\title{
Amat-Piniella, Joaquim. K.L. Reich. Waterloo: Wilfrid Laurier University Press, 2014.
}

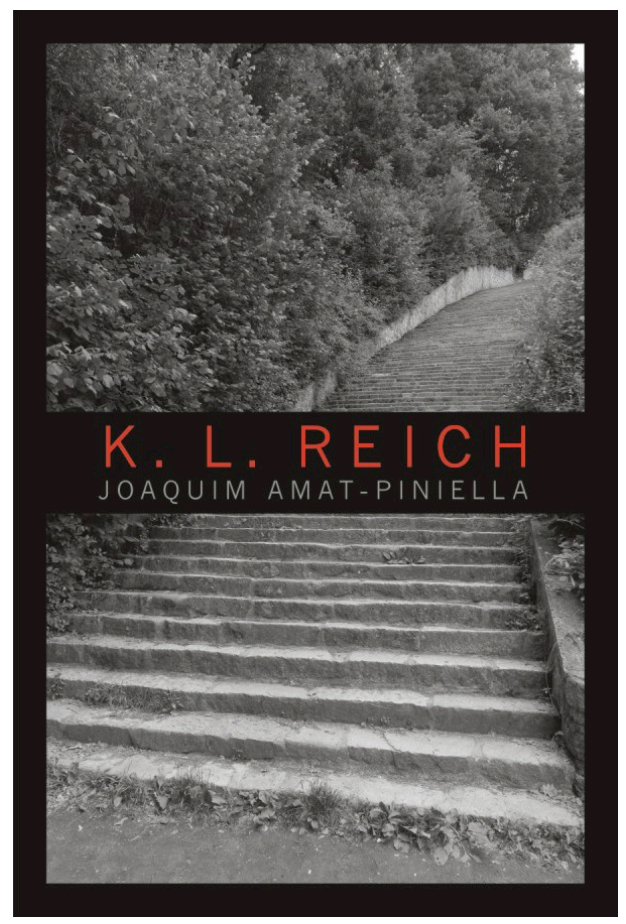

\author{
Chris Reyns-Chikuma \\ University of Alberta, Canada
}

In 1945, after having spent five years in one of the Mauthausen concentration camps as a Spaniard/stateless political opponent, Joaquim Amat-Piniella writes in Catalan about his holocaust experience. The manuscript is finally accepted in 1963 by the Spanish-Catalan publisher Club Editor after going through many obstacles due partly to the censorship of the Franco Regime. However, this first publication is a Spanish translation of the Catalan manuscript done in collaboration with Carlos Barral, himself an influential editor of books in Spanish (xiii). It is only some months later that the same publisher published the Catalan original version. One can guess that it is for marketing reasons that it was first translated and published into Spanish since the Spanish market is much bigger than the Catalan one, even more so in the 1960s. A "new" version in Catalan is edited in 2001 by David Serrano (who had previously defended his dissertation on the book-L'bora blanca. L'bolocaust i Joaquim Amat-Piniella, 2004), "based on the 1946 typed-manuscript version of the novel" (xv), and published by the Catalan publishing house Edicions 62. However, this 2013 first English translation is based on the 1963 version. The translators explained that Amat-Piniella "considered it the definitive one. That edition also offers the most polished use of Catalan, as it is very likely reworked with the guidance of the Catalan editor Joan Sales" (xv). In their "note on the translation," Robert Finley, one of the two translators, explains that the "English of [their] translation tends toward this shared Latin lineage as a way of underlining the presence of the Catalan text behind the one you have in your hands" (xxiii). 
They add that it also reinforces a distanciation effect already present in Amat-Piniella's style which is made of "a certain formality and reserve" typical of the "mid-century literary Catalan". Finley continues, saying that "it can produce a sense of detachment not only as regards the narrative voice in relation to what it narrates but also the reader in relation to what is being narrated" (xxiii). Finally, Finley writes that this formal style is also due to the writer's interest in science (xxiii), although without explaining his interpretation (we don't know where Amat-Piniellas's scientific interest comes from). The introduction completes the contextualization of Amat-Piniella's "novel" by situating the text within the many other texts produced by other survivors facing the same aporia: on the one hand, the "unspeakability", the fact that the horror cannot be spoken/told, and on the other, a compulsion to testify as an ultimate act of resistance against forgetting such a unique horrible experience of the concentration camp, creating at the same time an empathy with the victims while keeping a sufficient distance for reflection about the text and the experience. In AmatPiniella's case the resistance was possible sooner because, as shown in the "fiction," the political prisoners, although still treated with extreme cruelty and sadism, were in a better situation than the Jewish prisoners. This is even more the case for the translators in the camps who were in a privileged position because he was needed and "useful." Hence, proportionally many more Spaniards survived the camps as already discussed by the work of the most famous "Spanish" holocaust witness-writer, i.e. Jorge Semprún (cited here: xiii; see Reyns-Chikuma).

That thesis is reinforced by the fact that "the first published testimonial works focused on the political resistance in the camps rather than the specific experiences of the Jews" (xiv). Some of these experiences though were told in the form of testimonials or reflections such as those by Rousset, Antelme, and Cayrol, who did not believe that it was possible and desirable to relate those events as fiction (xvii). With her introduction, Marta Marín-Dómine brings to our knowledge the quite recent research on the Spanish prisoners, citing studies by David Pike's Spaniards in the Holocaust: Mauthausen, Horror on the Danube (2000), including the refugee camps for Republicans in France (see Peschanski).

Holocaust literature is extensive. Nazi Extermination camps are most infamous for exterminating Ethnic untermensch like Jewish Roma or mentally challenged people. Less known is the fact that camps like Mauthausen were open for political opponents to other regimes like the Spanish Franco dictatorship. Semprún is probably the most famous of these opponents in France and in translation. In his preface, Amat-Piniella explains why he chose the form of the novel:

[B]ecause it seems to us the most faithful to the inner truth of those of us who lived through those circumstances. After all that has been said about the camps with the cold eloquence of numbers and all the stories that have appeared in the press, we believe that through the lives of some few characters, real or not, we have been able to give a truer and more vital impression than if we had limited ourselves to an objective exposition. (xvii) 
In the introduction though, the translators present the "novel» more as a "testimonial using a fictional third person" (5).

This University Press book, which contains 42 endnotes (3 pages) for the introduction and ends with 54 endnotes ( 6 full pages), is not intended for a wider audience but it will be useful as a teaching tool in various courses on translation (Spanish/Catalan/English), on History and on Holocaust Literature, giving a different perspective on the camps and on the writing of an experience that unfortunately seems to repeat itself or rather is reproduced again and again by human beings everywhere on the planet after one thought that their "testimonials" would ensure that it would happen "never again"!

\section{REFERENCES}

Peschanski, Denis. La France des camps: L’internement, 1938-1946, Paris: Gallimard: 2002. Print.

Reyns-Chikuma, Chris. "L’Écriture ou la vie”. World Literature Today 71.1 (1998): 236. Print. 